\title{
AMYOTROPHIC LATERAL SCLEROSIS IN BRAZIL
}

\author{
1998 NATIONAL SURVEY
}

\author{
FLÁVIA DIETRICH-NETO*, DAGOBERTO CALLEGARO**, ELZA DIAS-TOSTA***, \\ HELGA ALMEIDA SILVA****, MARIA ELIZABETH FERRAZ*****, \\ JOSÉ MAURO BRAZ DE LIMA******, ACARY SOUZA BULLE OLIVEIRA*******
}

\begin{abstract}
Objectives: To assess the epidemiologic characteristics of amyotrophic lateral sclerosis (ALS) in Brazil in 1998. Method: Structured Clinical Report Forms (CRFs) sent to 2,505 Brazilian neurologists from January to September 1998 to be filled with demographic and clinical data regarding any ALS patient seen at any time during that year. Results: Five hundred and forty CRFs were returned by 168 neurologists. Data on 443 patients meeting the criteria of probable or definite ALS according to El Escorial definition were analysed: 63 probable $(14.2 \%)$ and 380 definite $(85.8 \%)$. Two hundred and fifty-nine $(58.5 \%)$ of the patients were male, mean age of onset was 52. Spinal onset occurred in 306 patients (69\%); bulbar onset in $82(18.5 \%)$, and both in $52(11.7 \%)$. Twenty-six (5.9\%) had a family history of ALS. Two hundred and fifty-nine (58.6\%) were seen by private practitioners, and $178(40.2 \%)$ at a hospital clinic. Age-ajusted incidence shows a peak incidence at the 65-74 years old range. Conclusions: The disease's characteristics are similar to those described in international studies, except for age of onset (Brazilian patients are younger). This difference is not confirmed when figures are age-adjusted.
\end{abstract}

KEY WORDS: amyotrophic lateral sclerosis, ALS, epidemiology, prevalence, incidence.

\section{Esclerose lateral amiotrófica no Brasil: registro nacional, 1998}

RESUMO - Objetivos: Avaliar as características epidemiológicas da esclerose lateral amiotrófica (ELA) no Brasil durante o ano de 1998. Método: Formulários estruturados enviados a 2.505 neurologistas brasileiros de janeiro a setembro de 1998 para serem preenchidos com dados demográficos e clínicos de todos os pacientes com ELA atendidos no ano de 1998. Resultados: Quinhentos e quarenta formulários retornaram, enviados por 168 neurologistas. Dados sobre 443 pacientes que se enquadravam nos critérios de ELA provável ou definida de acordo com El Escorial foram analisados: 63 provável $(14,2 \%)$ e 380 definida $(85,8 \%)$. Duzentos e cinquenta $(58,5 \%)$ eram do sexo masculino. A idade média de aparecimento dos primeiros sintomas foi de 52 anos. O início em membros ocorreu em 306 pacientes (69\%), bulbar em 82 (18,5\%) e generallizada em $52(11,7 \%)$. Vinte e seis $(5,9 \%)$ tinham história familiar. Duzentos e cinquenta e nove $(58,6 \%)$ foram atendidos em clínicas ou consultórios, e 178 (40,2\%) em ambulatório de hospital. Ajustando para a distribuição da população brasileira segundo faixa etária, a maior incidência ocorre entre 65 e 74 anos de idade. Conclusões: As características epidemiológicas da doença são semelhantes àquelas descritas em estudos internacionais, exceto para idade dos primeiros sintomas (pacientes brasileiros são mais jovens). Esta diferença desaparece quando os valores são ajustados para idade.

PALAVRAS-CHAVE: esclerose lateral amiotrófica, ELA, epidemiologia, prevalência, incidência.

Amyotrophic lateral sclerosis (ALS) is an invariably fatal neurodegenerative disease encompassed in the spectrum of neuromuscular disorders (NMD) and characterized by progressive

*MD, PhD, Aventis Pharma, Medical Manager, São Paulo, Brazil; **MD, PhD, Hospital das Clínicas da Universidade de São Paulo (FMUSP), Neurology Department, ***MD, PhD, Hospital de Base do Distrito Federal, Head of Neurology Unit, Brasília, Brazil; ****MD, PhD, Hospital das Clínicas da FMUSP, Neurology Department, *****MD, PhD, Universidade Federal de São Paulo (UNIFESP), Neurology Department; ******MD, PhD, Universidade Federal do Rio de Janeiro, Neurological Institute, Rio de Janeiro, Brazil; *******MD, PhD, UNIFESP, Neurology Department, São Paulo, Brazil. Aceite: 11-abril-2000.

Dra. Flávia Dietrich Neto - Rua Vieira de Moraes 74/162A - 04617000 São Paulo SP - Brasil. 
loss of upper and lower motor neurones, leading to muscle weakness and death. Usually $50 \%$ of the patients die within 3-4 years of symptoms onset ${ }^{1}$. The only available drug treatment, riluzole, prolongs life but has not been shown to prevent the disease's fatal outcome ${ }^{2}$. ALS's incidence and prevalence rates vary widely from one country to another. The prevalence may range from $0.8 / 100,000$ population in Mexico, to 8.4/100,000 in $\mathrm{UK}^{3}$. This variation can be related to underdiagnosis, but race as well as latitude have been held at least partially responsible for such differences ${ }^{4}$. In Brazil, there is little epidemiologic data available. Due to the disease's short course and fatal outcome, the mortality rate could be an indirect measure of the incidence rate ${ }^{5}$, but more than $15 \%$ of the death certificates in Brazil state "unknown causes" as underlying cause of death, making national results unreliable as a whole ${ }^{6}$, except for some rare regional surveys.

Three Brazilian incidence studies, based on adjudicated death certificates are worth mentioning. In the study by Lima et al. death certificates from the city of Rio de Janeiro, covering 10 years (1965-74), were analysed. ALS's annual mortality rate ranged from 0.3 to $0.9 / 100,000$ population? The highest rates were observed in the years 1971 through 73. In Gomes' survey, 1979 through 1986, the annual mortality rate ranged from 0.35 to $0.55 / 100,000$ in Rio de Janeiro city ${ }^{8}$. In 1998 , an updated survey by Moraes found ALS mortality to vary from 0.2 to $0.32 / 100,000$ in $91-94$, in the city of São Paulo, and 0.36-0.41/100,000 during the years 1995 through 97 (Table 1) ${ }^{9}$.

To date, in Brazil, no attempt has been made to put together a comprehensive database to assess ALS's other epidemiologic aspects, such as sex distribution, time from onset to diagnosis and tests performed. Such studies are confined to referral centers. In 1983, a study from Rio de Janeiro, analysing data on 136 patients showed $68 \%$ were male, $75 \%$ had limb onset, $80 \%$ presented their first symptoms before 60 years old ${ }^{7}$. In 1998, a study from São Paulo on 51 patients from yet another referral center found a male to female ratio of 1.7 , limb onset in $78 \%$, familial ALS in 4\%. ${ }^{10}$ In 1999 , a retrospective study performed on 78 patients from Ceará (a northeastern state) found $21 \%$ of them to be of juvenile (15-29 years old) sporadic form. Ninety-one percent had spinal onset, and malefemale ratio was $1.8 / 1^{11}$.

Brazil's dimensions (>8 million $\mathrm{km} 2,160$ million inhabitans, 4,500 neurologists), inequities regarding access to health services, and the lack of a patient association, as of 1998, were other factors to hinder the epidemiologic knowledge of the disease. The present study was designed to bridge this gap, assessing the disease's characteristics in a compreehensive survey. The primary objective was to assess demographic and disease data from as many ALS patients as possible, seen in 1998, irrespective of the date of diagnosis, and diagnosed with probable or definite ALS according to the World Federation of Neurology (WFN) criteria ${ }^{12}$. Our patient population should be as comprehensive as possible, coming from referral centers as well as private clinics, in order to compare it to other countries' data, and to avoid the bias described by Lee et al. in 1995: when comparing the outcome of ALS patients from the general population to that of a referral center, the authors found that the 5-year survival rate was $4 \%$ for the cohort as compared to $21 \%$ for the referral center population, due to factors independent of treatment ${ }^{13}$.

\section{METHOD}

From January to September 1998, invitation letters and forms were sent to 2,505 neurologists found through HMO booklets, congress lists and the Brazilian Neurological Association, describing the study's objectives and asking them to fill a one-page long clinical research form (CRF) per patient under his/her care in 1998. Each neurologist received initially 2 blank forms to be filled with his patients' data. Mail charges were pre-payed.

Data were collected on demography (sex, date and place of birth, place of consultation) and disease characteristics (date of symptoms' onset; date of diagnosis; date of death; classification according to El Escorial criteria; family history; site of onset; tests performed).

Interim analyses were performed every 3 months, and reports were sent to all participating (responding) doctors.

A control of the number of CRFs sent and received from each physician, and an immediate trigger of more blank CRFs prevented them from running out of forms, and more forms could be sent upon request. 
Table 1. Summary of epidemiologic studies on ALS

\begin{tabular}{|c|c|c|c|c|c|c|c|c|c|c|}
\hline Author (ref) & Region & Year(s) & $\begin{array}{l}\text { Incidence } \\
(/ 100,000)\end{array}$ & Prevalence & $\begin{array}{c}\text { Time } \\
\text { to } \\
\text { diagnosis } \\
(\mathrm{mo})\end{array}$ & Survival & $\begin{array}{l}\text { Age } \\
\text { of } \\
\text { onset }\end{array}$ & $\begin{array}{l}\mathrm{M}: \mathrm{F} \\
\text { ratio }\end{array}$ & $\begin{array}{l}\text { spinal } \\
\text { onset } \\
(\%)\end{array}$ & $\begin{array}{c}\text { Familial } \\
(\%)\end{array}$ \\
\hline $\begin{array}{l}\text { Neilson }^{24} \\
1993\end{array}$ & France & $\begin{array}{l}68 \\
90\end{array}$ & $\begin{array}{l}1.1^{*} \\
1.9^{*}\end{array}$ & & & & & & & \\
\hline $\begin{array}{l}\text { Bettoni }^{14} \\
1994\end{array}$ & $\begin{array}{l}\text { Italy / } \\
\text { Parma }\end{array}$ & $60-90$ & 0.98 & $\begin{array}{c}2.5 \\
(1981)\end{array}$ & & $\begin{array}{l}\text { mean } \\
30 \mathrm{mo}\end{array}$ & 60 & 1.2 & 62 & \\
\hline $\begin{array}{l}\text { Giagheddu17 } \\
1993\end{array}$ & $\begin{array}{l}\text { Italy / } \\
\text { Sardinia }\end{array}$ & $57-90$ & 0.68 & $\begin{array}{c}2.26 \\
(1985)\end{array}$ & & $\begin{array}{c}\text { median } 30 \\
\text { mean } 36\end{array}$ & 56 & 1.8 & 51 & \\
\hline $\begin{array}{l}\text { Chió }^{5} \\
1992\end{array}$ & $\begin{array}{l}\text { Italy / } \\
\text { Piemonte }\end{array}$ & & & & & & & 1.6 & & \\
\hline $\begin{array}{l}\text { Chió }^{15} \\
1993\end{array}$ & Italy & $58-87$ & 0.68 & & & & & $1.4^{*}$ & & \\
\hline $\begin{array}{l}\text { Tysnes }^{27} \\
1991\end{array}$ & $\begin{array}{l}\text { Norway / } \\
\text { Hordaland }\end{array}$ & $79-88$ & $\begin{array}{l}1.6^{*} \\
(0.77-2.8)\end{array}$ & $\begin{array}{c}3.67 \\
(1988)\end{array}$ & $\begin{array}{c}\text { mean } \\
30\end{array}$ & $\begin{array}{c}\text { median } \\
28\end{array}$ & 61 & 1.3 & 51 & \\
\hline $\begin{array}{l}\text { Scottish } \\
\text { Group }^{26} \\
1992\end{array}$ & Scottland & 89 & 2.24 & & & & & & & \\
\hline $\begin{array}{l}\text { López- } \\
\text { Veiga }^{22} \\
1988\end{array}$ & $\begin{array}{l}\text { Spain / } \\
\text { Cantabria }\end{array}$ & $74-85$ & 1.01 & 3.52 & median 11 & $\begin{array}{c}\text { mean } \\
26.6 \mathrm{mo} \\
60 \% 24 \mathrm{mo}\end{array}$ & $\begin{array}{l}58 \mathrm{M} \\
64 \mathrm{~F}\end{array}$ & 1.78 & 61 & \\
\hline $\begin{array}{l}\text { Veiga- } \\
\text { Cabo }^{28} \\
1997\end{array}$ & Spain & $51-90$ & $1.49 *$ & & & & & & & \\
\hline $\begin{array}{l}\text { Stallones }{ }^{25} \\
1989\end{array}$ & $\begin{array}{l}\text { USA / } \\
\text { Kentucky }\end{array}$ & $\begin{array}{l}59-61 \\
64-67 \\
68-78 \\
79-84\end{array}$ & $\begin{array}{l}0.4 \\
\text { M1.05/F0.56* } \\
\text { M1.08/F0.58* } \\
\text { M1.23/F0.76* }\end{array}$ & & & & & $\begin{array}{l}1.79 \\
1.86 \\
1.62\end{array}$ & & \\
\hline $\begin{array}{l}\text { Lee }^{13} \\
1995\end{array}$ & $\begin{array}{l}\text { USA/ } \\
\text { Texas }\end{array}$ & $85-88 * *$ & & & & $\begin{array}{c}\text { median } \\
21.3\end{array}$ & 59.5 & 1.1 & 59 & 2.1 \\
\hline $\begin{array}{l}\text { Haverkamp } \\
1995\end{array}$ & $\begin{array}{l}\text { ALS Clinic } \\
\text { database/ } \\
\text { Baylor Colle }\end{array}$ & $83-95$ & & & & $\begin{array}{c}\text { Mean } \\
33.6 \\
\text { median } \\
29.1\end{array}$ & 55.7 & 1.7 & 75 & 9.5 \\
\hline $\begin{array}{l}\text { Mc Guire } \\
1996\end{array}$ & $\begin{array}{l}\text { USA / } \\
\text { Western } \\
\text { Washington }\end{array}$ & 90-95 & $\begin{array}{l}1.8 \text { crude } \\
2.1 \mathrm{M} / \\
1.9 \mathrm{~F}^{*}\end{array}$ & & & & $\begin{array}{l}57 \mathrm{M} \\
65 \mathrm{~F}\end{array}$ & 1.2 & & \\
\hline $\begin{array}{l}\text { Longstreth }^{21} \\
1998\end{array}$ & $\begin{array}{l}\text { USA / } \\
\text { Washington } \\
\text { \& others }\end{array}$ & $90-94$ & & & & & & 1.2 & & \\
\hline $\begin{array}{l}\text { Larreatgui }^{19} \\
1988\end{array}$ & Panama & $74-85$ & & & & & $41-50$ & 1.2 & & \\
\hline $\begin{array}{l}\text { Mitchell }{ }^{23} \\
1990\end{array}$ & $\begin{array}{l}\text { UK / } \\
\text { Lancashire } \\
\text { \& South } \\
\text { Cumbria }\end{array}$ & $76-86$ & 1.86 & & & & & 1.6 & & \\
\hline $\begin{array}{l}\operatorname{Lima}^{7} \\
1883\end{array}$ & $\begin{array}{l}\text { Brazil / } \\
\text { Rio de } \\
\text { Janeiro }\end{array}$ & $65-74$ & $0.3-0.9$ & & & & & 1.1 & & \\
\hline $\begin{array}{l}\text { Gomes }^{8} \\
1991\end{array}$ & $\begin{array}{l}\text { Brazil / } \\
\text { Rio de } \\
\text { Janeiro }\end{array}$ & $79-86$ & 0.4 & & & & & 1.7 & & \\
\hline $\begin{array}{l}\text { Almeida } \\
\text { Silva }^{10} \\
1998\end{array}$ & $\begin{array}{l}\text { Brazil / } \\
\text { São Paulo }\end{array}$ & NS & & & & & & 1.7 & 78 & 4 \\
\hline $\begin{array}{l}\operatorname{Lima}^{20} \\
1998\end{array}$ & $\begin{array}{l}\text { Brazil// } \\
\text { Rio de } \\
\text { Janeiro }\end{array}$ & NS & & & & & & 1.0 & 61 & 4 \\
\hline $\begin{array}{l}\text { Moraes }{ }^{9} \\
1998\end{array}$ & $\begin{array}{l}\text { Brazil / } \\
\text { São Paulo }\end{array}$ & $\begin{array}{l}91-94 \\
95-97\end{array}$ & $\begin{array}{l}0.2-0.32 \\
0.36-0.41\end{array}$ & & & & & & & \\
\hline $\begin{array}{l}\text { Castro- } \\
\text { Costa }^{11} \\
1999\end{array}$ & $\begin{array}{l}\text { Brazil// } \\
\text { Ceará }\end{array}$ & $80-99$ & & & & Mean 30 & 43 & 1.8 & 91 & \\
\hline
\end{tabular}

*age-adjusted; **time of diagnosis; M, male; F, female; NS, not specified. 
All doctors were mailed a "recall" letter, reminding them of the survey, as well as an interim report. The study ended in April 1999, and a final report was issued to all participating physicians in June 1999.

Descriptive statistics were used for demographic data. Chi-square test was used to test the null hypothesis of independence for onset form according to gender.

\section{RESULTS}

One hundred and sixty-eight neurologists sent 540 forms on 511 patients (duplicate forms were eliminated). Of those, 443 meeting the criteria of "probable" or "definite" ALS were analysed.

Two hundred and fifty nine patients $(58,5 \%)$ were male, yielding a male to female ratio of $1.4 / 1$. One hundred and thirty $(29,3 \%)$ were born in the state of São Paulo (SP) and $10.4 \%$ in the state of Rio de Janeiro (RJ), the 2 most populous states (Fig 1). Twenty-one (4.7\%) were born outside the country. It is worth noticing that $202(45.6 \%)$ of the patients were followed in SP, and 60 $(13,5 \%)$ in RJ, which may reflect the higher concentration of referral centers and physicians in these states.

Two hundred and fifty-nine (58.5\%) were followed at private clinics, $178(51.5 \%)$ at hospitals.

Mean age of onset was 52 years old $(\mathrm{SD} \pm 13)$, median 52. Age distribution at time of onset shows a higher frequency at ranges 50 to 54 and 55 to 59 years old (14 and $12.4 \%$, respectively). Eighty (18.1\%) of the patients presented their first symptoms under the age of 40 (Fig 2).

Of the 443 patients, 380 (85.8\%) had definite, and 63 (14.2\%) probable ALS.

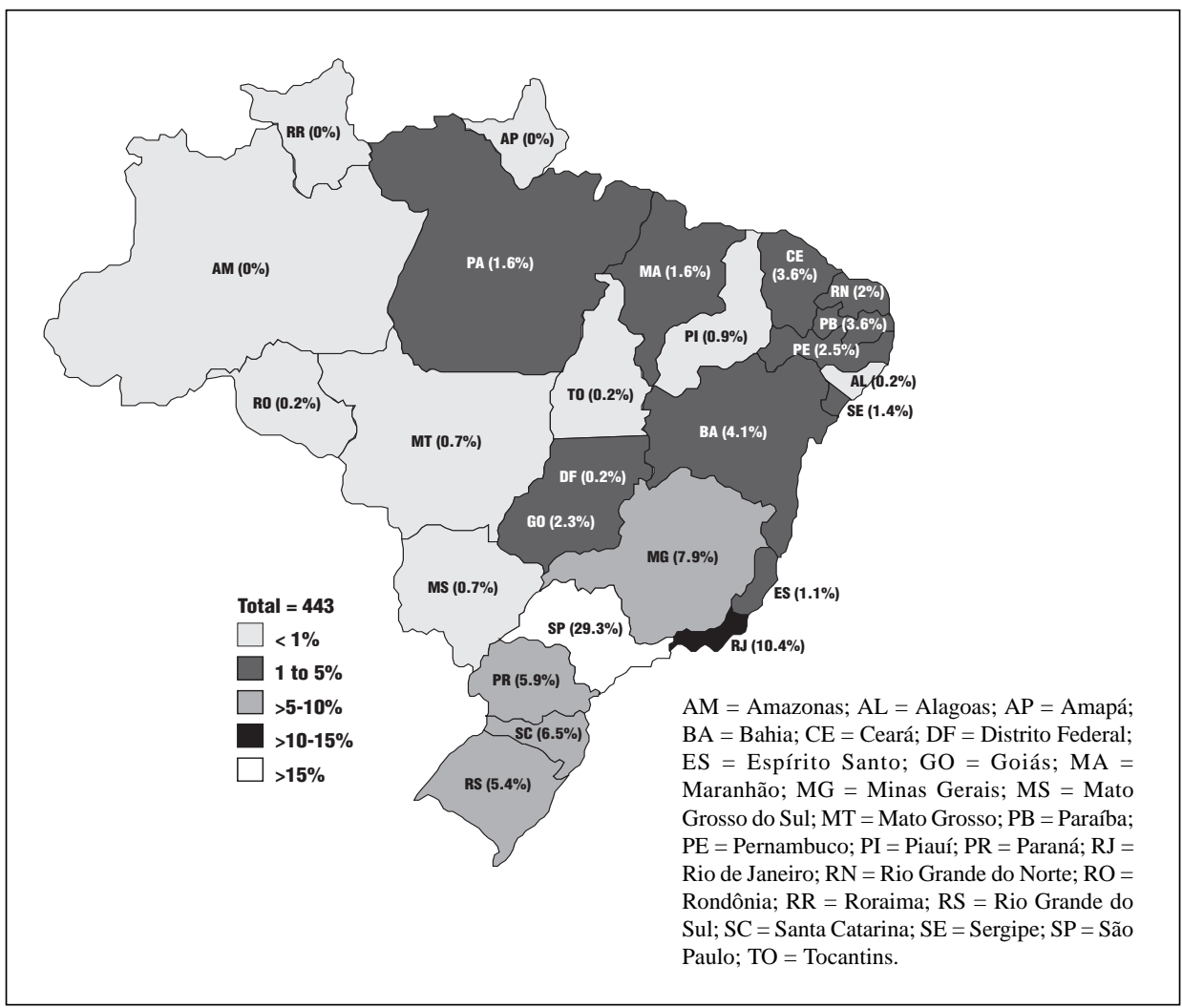

Fig 1. Patient distribution according to place of birth. 


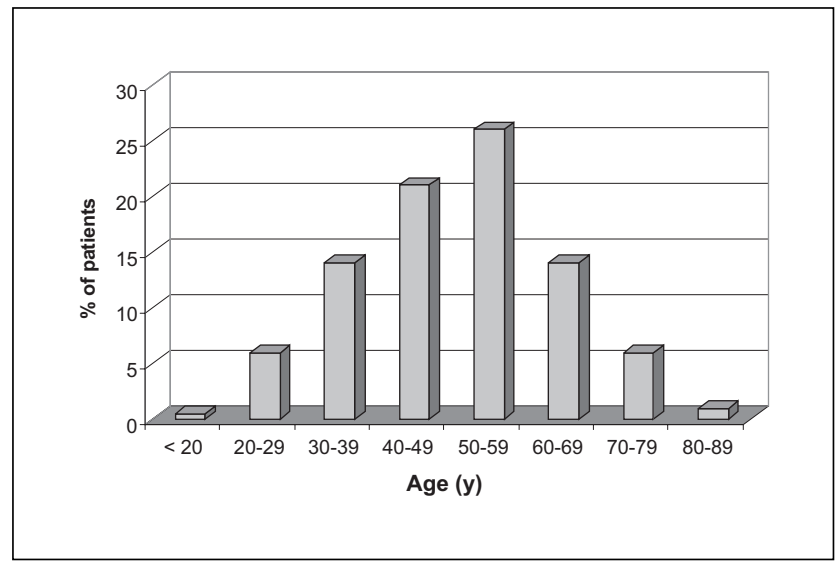

Fig 2. Age of onset. $n=443$.

Table 2. Sex distribution according to clinical form, time from first symptoms to diagnosis, age of onset and survival.

\begin{tabular}{cccc}
\hline Characteristic & Male & Female & All \\
\hline Clinical form* & $\mathrm{N}(\%)$ & $\mathrm{N}(\%)$ & $\mathrm{N}(\%)$ \\
Bulbar & $38(15)^{* *}$ & $44(24)^{* *}$ & $82(18.5)$ \\
Limb & $187(73)$ & $118(65)$ & $306(69.1)$ \\
Both & $32(12)$ & $20(11)$ & $52(11.7)$ \\
Time from $1^{\text {st }}$ symptoms & & & \\
to diagnosis (months) & $17(30)$ & $20(25)$ & $18(28)$ \\
Mean $( \pm$ SD) & 10 & 12 & 11 \\
Median & $0-332$ & $0-210$ & 0 to 332 \\
Range & & & $52(13)$ \\
Age of onset (years) & $50(13)$ & $54(13)$ & 52 \\
Mean $( \pm$ SD) & 51 & 54 & \\
Median & $\mathrm{N}=13$ & $\mathrm{~N}=10$ & $42(37)$ \\
Survival $(23$ patients $)$ & & $33(18)$ & 7 to 191 \\
(months) & $49(46)$ & 9 to 191 & \\
Mean $( \pm$ SD) & 7 to 60 & & \\
Range & &
\end{tabular}

*Data missing on 3 patients

$* * \mathrm{p}<0,05$

Spinal onset was the most frequent clinical form, present in $306(69 \%)$ of the patients. Of note, spinal onset occurred more frequently in men than in women ( $73 \%$ vs $65 \%, \mathrm{p}=0,045)$ (Table 2$)$.

Time from first symptoms to diagnosis varied widely: from 0 to 332 months (Table 2).

Distribution according to inheritance and age is shown in Table 3.

Electroneuromyography was the most performed test: 416 patients (94\%) (Figure 3).

Only $23(5,2 \%)$ deaths were reported (6 in bulbar, 13 in spinal and 4 in generalized onset). Time from first symptoms to death ranged from 7 to 191 months, and there was a trend towards a shorter survival among bulbar patients (median 23 vs 32 months in spinal ALS) (Table 4). 
Table 3. Mean age of onset in familial and sporadic cases

\begin{tabular}{ccc}
\hline "Inheritance" & Sporadic & Familial \\
\hline Age of onset (y) & & \\
Mean ( \pm SD) & $52(13)$ & $47(13)$ \\
Median & 53 & 45 \\
Number of patients $(\%) *$ & $403(91)$ & $26(5.9)$ \\
\hline
\end{tabular}

*Data missing on 14 patients

Table 4. Survival in bulbar and spinal patients according to type of onset $(N=19$ patients $)$

\begin{tabular}{ccc}
\hline Type of onset & Spinal & Bulbar \\
\hline Survival (mo) & & $32(22)$ \\
Mean $( \pm$ SD) & $48(46)$ & 23 \\
Median & 32 & $7-54$ \\
Range & $9-191$ & \\
\hline
\end{tabular}

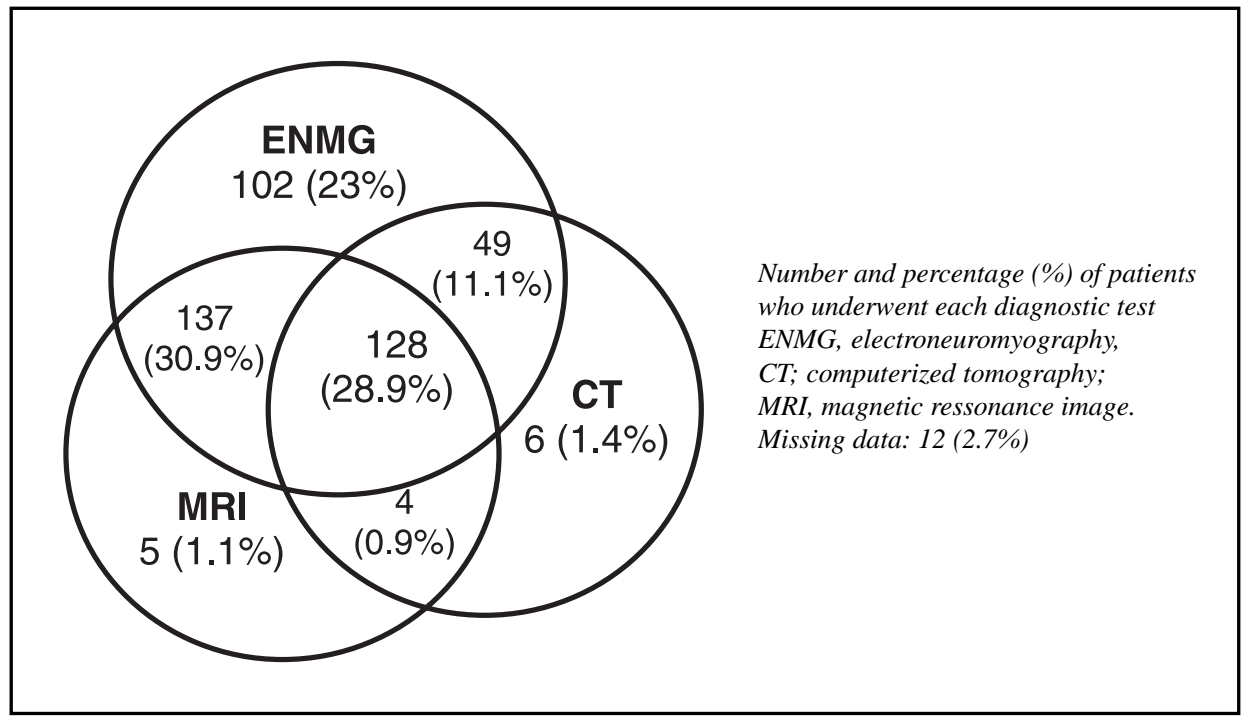

Fig 3. Tests performed.

\section{DISCUSSION}

Regional published data concerning ALS mortality in Brazil, where it is fairly reliable (São Paulo and Rio de Janeiro cities), infers an incidence rate of 0.3-0.5/100,000 population. Considering the mean duration of the disease to be 3 years (Table 1), this yields a disease prevalence of about 1,440 to 2,400 cases in Brasil ( 0.9 to $1.5 / 100,000$ inhab), lower than that described in Europe and USA. The patient population under analysis in this study represents roughly one-fifth to one-third of the ALS population in the country, from referral centers as well as private practices, which helps avoiding biases. 
There is no data about the exact number of neurologists practicing in Brazil. Federal Medical Council acknowledges some 4,500 neurologists, but this is an estimate. More than 3,500 neurologists were notified of the study, but participation was voluntary.

Most disease and demographic characteristics (such as earlier onset in the familial form, male-to-female rates, survival, type of onset) in this study are similar to those observed in other countries as well as in other Brazilian studies (Table 1) 3 , 4,7-11,13-28

The shorter survival time in bulbar onset is consistent with the published literature, and as women had bulbar onset more frequently than men, this may explain why time from first symptoms to death was shorter for females. Nevertheless, drawing conclusions from the small number of patients whose death was reported (23 patients) may be hazardous. Still, the higher rate of bulbar onset among women has not, to our knowledge, been described before, and it may be a Brazilian peculiarity.

ALS's most frequent age of onset, in this sample, is 50-60 years old, with a median of 52. In European countries, ALS's first symptoms occurs more frequently between 59 and 65 years old. This difference is probably due to the different age stratification of our population, younger than the European and American ones. If we calculate the study prevalence in each age strata using the Brazilian population distribution in 1997, the age of onset peaks between ages 65 and 74 (the same as in other countries) ${ }^{16}$. In spite of that, we cannot overemphasize the need to consider the possibility of an ALS diagnosis in a relatively young patient: half the patient population is less than 52 years old when first symptoms occur.

Using São Paulo city's ALS-related mortality as an index of Brazil's mortality, the approximate crude incidence rate in Brazil is 0.4/100,000. The crude prevalence would be about 1.2/100.000, and the total number of patients in Brazil, 1,920. Using the US 1994 population as a standard and the age-adjusted "study prevalence", if we had the same age distribution as in the US, 1011 patients would be in the study, and there would be circa 8,300 patients in the country, yielding an ageadjusted prevalence of 5.2/100,000, and an age-adjusted incidence of 1.7/100,000, still lower than the US incidence, which is approximately $2 / 100,000^{3,29,30}$.

We have to bear in mind that age distribution in São Paulo is not the same as in the rest of the country ${ }^{16}$. In São Paulo, the older strata are over-represented, which may lead to an over-estimatition of the Brazilian incidence.

Although age-adjusted mortality due to ALS is increasing worldwide, a French study based on Grompetzian analysis showed this increase is rather due to disease competition than to change in environmental factors. That is, people are dying from ALS because they are not dying from other disease $^{24}$. As therapeutic progress is slow, the social burden due to the disease is bound to increase.

Not surprisingly, ENMG is still an essential diagnostic tool, and MRI is progressively replacing $\mathrm{CT}$ as it allows better differentiation from other diseases, thus shortening the time to diagnosis ${ }^{31}$.

The study's major limitation is the possible bias created by voluntary participation. As we do not have precise mortality data, we also have very little background against which to compare our results. This is one of the reasons why patients whose disease classification was "possible", "suspect" (according to El Escorial criteria) or was not specified, were not included in this analysis: in order to limit misdiagnosis, an ever-present problem in $\mathrm{ALS}^{32,33}$.

The sample analised is numerically significant, considering the disease's relatively low incidence. It is the largest cohort analysed to date in Brazil, and the inclusion of referral centers' as well as private clinics' data reinforce the reliability of the results.

\section{Conclusions}

Even though at first glance ALS seems to behave differently in Brazil than it does in Europe and North America, it now appears that the differences between are small. Except for lower age of onset in Brazil, due to difference in age stratification, and for a higher incidence of bulbar onset 
among women, in every other aspect encompassed here, it shows the same clinical pattern as in European and North-American countries. More epidemiologic studies are needed in order to assess other variables, such as disease duration and management, which were outside the scope of this study.

Acknoweledgements - Thaïs Cocarelli and Renata Holender, Rhodia Farma, for data management. The following participating physicians: name, state (number of patients).

Acary Oliveira, SP (35), Achieles C Ribeiro, MA (1), Adriana Dutra de Oliveira, SP, (3), Adroaldo Baseggio Mallman, RS (1), Alberto Alain Gabbai, SP, (1), Alcides Codeceira Jr, PE (2), Alexandre Ottoni Kaup, SP (2), Allan Zimerman, SP (3), Alzira A Carvalho, SP (8), Amilton Barreira, SP (4), Ana Emilia de Souza Matos, BA (1), Anderson Kuntz Grzesiuk, MT (2), André Sobierajdski dos Santos, SC (4), Andrea Bacelar, RJ (1), Andrea Temponi Lebri, SP (1), Angelina Maria Martins Lino, SP (1), Antonio Andrade, BA (8), Antonio Cezar Ribeiro, SP (2), Antonio Manuel Borba Jr, RS (1), Antonio Ronaldo M.C., MG (1), Beatriz C Vieira, SP (1), Boaventura D da Silva, RS (1), Carlos A Foderati Machado, RS (3), Carlos Alberto Almeida Boer, PR (3), Carlos Augusto Adamy, RS (1), Carlos Bernardo Tauil, SP (1), Carlos E B Cavalcante, MA (2), Carlos Henrique dos Santos, SP (1), Carlos Mauricio Castro Costa, CE (10), Celso David Lago, RS(1), Charles Andre, RJ (1), Ciro Pereira de Rezende, PR (9), Cláudia Alves Cunha, RS (1), Cláudia Veiga de Castro, SP (1), Cláudio Henrique do Amaral, SC (2), Cynthia D Pinheiro, RJ (1), Dagoberto Callegaro, SP (18), Delson J da Silva, GO (2), Edimar Zanoteli, SP (1), Edoardo Arturo V Medugno, SP (1), Edrin Claro O Vicente, PR (1), Egeu Bosse, MS (1), Elaine Aparecida Pignata, SP (2), Elany Rosevics, PR (1), Elisabete Pedra de Matos, SP (1), Elizabeth M. Quagliato, SP (1), Elza Dias Tosta da Silva, DF (20), Enio Alberto Comerlato, RS (2), Estevão D Nascimento, SC (5), Eustáquio Claret dos Santos, MG (9), Fausto Oliveira Braga, RJ (1), Fernanda Bardy Bahadian, RJ (2), Fernando Alex de Souza, SC (4), Geraldo N. Rizzo, RS (2), Germany Gonçalves Veloso, SP (1), Getúlio D Rabello, SP (3), Gezis Maria Façanha, PA (3), Gladys L Martins, SC (1), Gustavo Nora, BA (1), Helga C. Almeida da Silva, SP (45), Homero Tocchetto, RS (1), Israel Roitman, SP (1), Israel Salmen Schulz, RJ (1), Ivan C Teixeira, RJ (1), Jaime Antunes Maciel Jr., SP (1), Jaime Seráffico, PA (4), Jean Carlos Shimazaki, PR (2), João B Mascarenhas, RJ (1), João Eliezer Ferri de Barros, SP (3), João Roberto Elias, SP (1), João V do Espírito Santo, RS (1), Jony Andrade Sobrinho, SP (3), Jorge El Kadum Noujaim, RJ (7), José Antonio Garbino, SP (3), José Geraldo Speciali, SP (2), José Lúcio de O Dantas, SE (1), José L. Sion Cantos, SC (1), José Luis Alonso Nieto, SP (1), José Mauro B Lima, RJ (20), José Sérgio Tomaz de S, SP (1), Jovany L Alves de Medeiros, PB (5), Leila Elizabeth F. de Paola, PR (5), Lilian Regina Gonçalves, SP (1), Lineu Werneck, PR (3), Lúcia Helena Neves Marques, MS (1), Luciana de Abreu Lima, RJ (1), Luciano Nogueira Filho, SP (1), Luís Del Carmem V Gutierrez, RS (1), Luís Eduardo M Rodrigues, ES (1), Luis Sidonio T da Silva, PR (5), Luiz Augusto Franco, SP (3), Luiz Alexandre C. Pinto, RJ (2), Luiz Boanerges Lima Ferreira, BA (6), Luiz C Coral, SC (2), Luiz Pascuzzi, SP (7), Luiz Paulo de Queiroz, SC (1), Magda Rocha Andrade, MG (1), Maier Sztajnberg, RJ (2), Márcia Waddington Cruz, RJ (2), Márcio Menna Barreto, RS (2), Marcos Seefeld, PR (2), Maria C Lacativa, RJ (2), Maria Cristina Giacomo, SP (2), Maria do Carmo Sitta, SP (1), Maria Elizabeth Ferraz, SP (35), Maria Tereza Alves Hirata, SP (1), Maria V Lima Machado, SP (1), Maria E Camargo, SP (1), Mário Emílio T Dourado, RN (10), Mario José Goes, SP (2), Mario Vicente Alves Junior, SP (2), Mário Wilson Brotto, SP (16), Marli Pernes da S Loureiro, RJ (9), Marly de Albuquerque, SP (2), Mary S Carvalho, SP (2), Maurílio Castro, SP (1), Mauro Guidotti Aquini, RS (1), Milton Miranda Fraga, RJ (1), Moacir Antonio Tenório, SP (1), Monica Haddad, SP (1), Murilo Rubens Schaefer, PR (1), Nabil Elias Bittar, SC (4), Norberto Luis Cabral, SC (1), Nerio D. Azambuja Jr., RS (2), Orleans A de Oliveira P, PR (4), Osmi Hamamoto, SP (1), Oswaldo Couto Jr., SP (4), Ozir Scarante, SP (2), Otto J.Hernandez Fustes, PR (2), Paulo Caramelli, SP (1), Paulo Eduardo M Carrilho, SP (3), Paulo Norberto de Sa, SC (1), Paulo Roberto A Rosa, RJ (1) Paulo Roberto de Brito Marques, PE (6), Paulo Roberto Taveira, GO (1), Paulo S Mendonça, PR (2), Pauzanes de Carvalho, RO (1), Pedro de Miranda Martins, MT (2), Regina M. Papais Alvarenga, RJ (1), Renan W. F. Vital, MG (1), Renata Parissi Buainain, SP (9), Renato P Lima, SP (1), Ricardo Oliveira Souza, RJ (1), Ricardo Orii, SP (1), Roberto da Cunha Wagner, RS (1), Roberto Hirsch, SP (1), Rogério Adas A de Oliveira, SP (1), Rosa Hasan, SP (2), Rubens J. Gagliardi, SP (3), Sebastião E Melo Souza, GO (8), Sergio A. Novis, RJ (4), Sergio Borges Bastos, BA (2), Silvia Raimunda Leite, MA (1), Solange Maria G G Camargo, RJ (3), Stenio H de Souza, SC (1), Suzana Dantas Gonçalves, SE (1), Telmo Tonetto Reis, RS (1), Teotonio Bia Tobias, MG (1), Thereza Cristina D Winkler, PR (4), Vanderci Borges, SP (2), Valdeir Domingues, GO (1), Vicente Leitão, CE (1), Viviane Flumignan Zétola, PR (2), Vitor Hugo Machado, RS (1), Wanda Ignatavicius, SP (1), Walter Oleschko Arruda, PR (5), Walter Roque Teixeira, SC (3), Wiviane Maria Rocha Pereira, SP (2), Yara Daldati Fragoso, SP (1) 


\section{REFERENCES}

1. Mitsumoto, H. Diagnosis and progression of ALS. Neurology, 1997;48:S2-S8.

2. Bensimon G, Lacomblez L, Meininger V. ALS Riluzole Study Group. A controlled trial of riluzole in amyotrophic lateral sclerosis. N Engl J Med, 1994;330:585-591.

3. Emery AHH. Population frequencies of neuromuscular diseases: II: amyotrophic lateral sclerosis (motor neurone disease). Neuromuscul Disord, 1991;1:323-325.

4. McGuire V, Longstreth WT, Koepsell TD, van Belle G. Incidence of amyotrophic lateral sclerosis in three counties in Western Washington State. Neurology, 1996;47:571-573.

5. Chiò A, Magnani C, Oddenino E, Tolardo G, Schiffer D. Accuracy of death certificate diagnosis of amyotrophic lateral sclerosis. J Epidemiol Community Health, 1992;46:517-518.

6. CENEPI/FNS/MS. Centro Nacional de Epidemiologia, 1996. http://www.fns.gov.br/cenepi/cenepi.htm

7. Lima JMB, Mesquita N, Duro LAA, Furtado AB. Epidemiological aspects of amyotrophic lateral sclerosis in Rio de Janeiro city. Rev Bras Neurol, 1983;19:75-78.

8. Gomes MM. Envelhecimento e o aumento das doenças amiotróficas : epidemiologia das doenças (crônicas ) das células do corno anterior da medula. Arq Bras Med, 1991;65:589-594

9. Moraes L, Goldbaum M, Silva HCA, Callegaro D. Incidence rate of amyotrophic lateral sclerosis (ALS) in Sao Paulo city, Brazil, 1991-1997. Arq Neuropsiquiatr, 1998;56(Supl 1):343.

10. Almeida Silva HC, Hirata MTA, Mansur L, Callegaro D, Marchiori PE, Scaff M. Amyotrophic lateral sclerosis (ALS) in Brazil : multidisciplinary and prospective evaluation of 51 patients (Abstr). Arq Neuropsiquiatr, 1998;56(Supl 1):342-343.

11. Castro-Costa CM, Oriá RB, Machado-Filho JA, et al. Amyotrophic lateral sclerosis. Clinical analysis of 78 cases from Fortaleza (northeastern Brazil). Arq Neuropsiquiatr, 1999;57:761-774.

12. World Federation of Neurology Research Group on Neuromuscular Diseases. El Escorial: World Federation of neurology criteria for the diagnosis of amyotrophic lateral sclerosis. J Neurol Sci 1994;124(Suppl):96-107.

13. Lee JRJ, Annegers JF, Appel SH. Prognosis of amyotrophic lateral sclerosis and the effect of referral selection. J Neurol Sci, 1995;132:207-215

14. Bettoni L, Bazzani M, Bortone E, Dascola I, Pisani E, Mancia D. Steadiness of amyotrophic lateral sclerosis in the province of Parma, Italy, 1960-1990. Acta Neurol Scand, 1994;90:276-280.

15. Chiò A, Magnani C, Schiffer D. Amyotrophic lateral sclerosis mortality in Italy, 1958 to 1987: a cross-sectional and cohort study. Neurology, 1993;43:927-430.

16. Datasus. Indicadores Demográficos Básicos. Ministério da Saúde, 1997. http://www.datasus.gov.br/cgi/idb97/demog.htm.

17. Giagheddu M, Mascia V, Cannas A, et al. Amyotrophic lateral sclerosis in Sardinia, Italy : an epidemiologic study. Acta Neurol Scand, 1993;87:446-454.

18. Haverkamp LJ. Natural history of amyotrophic lateral sclerosis in a database population. Validation of a scoring system and a model for survival. Brain, 1995;118: 707-719.

19. Larreatgui M, Gracia FJ, Jethmal E. Enfermedad de motoneurona anterior esclerosis lateral amiotrófica - Hospital Santo Tomas 1974-1985. Rev Méd, 1988;20:76-79.

20. Lima JMB, Pernes M, Portugal P, Pinto LAC, Reis CHM. Epidemiologic study of patients with amyotrophic lateral amyotrophic (Abstr). Arq Neuropsiquiatr, 1998;56(Supl 1):344.

21. Longstreth WT, Mcguire V, Koepsell TD, Wang Y, van Belle G. Risk of amyotrophic lateral sclerosis and history of physical activity. Arch Neurol, 1998;55:201:206.

22. López-Vega JM, Calleja J, Combarros O, Polo JM, Berciano J. Motor neuron disease in Cantabria. Acta Neurol Scand, 1988;77:1-5

23. Mitchell JD, Gibson NH, Gatrell A. Amyotrophic lateral sclerosis in Lancashire and South Cumbria, England, 1976-1986. Arch Neurol, 1990;47:875-880.

24. Neilson S, Robinson I, Alperovitch A. Rising amyotrophic lateral sclerosis mortality in France 1968-1990 : increased life expectancy and inter-disease competition as an explanation. J Neurol, 1994;241:448-455

25. Stallones L, Kasarskis EJ, Stipanowich C, Snider G. Secular trends in mortality rates from motor neuron disease in Kentucky, 1964-1984. Neuroepidemiology, 1989;8:68-78.

26. The Scottish Motor Neuron Disease Research Group. The Scottish motor neuron disease register : a prospective study of adult onset motor neuron disease in Scotland. Methodology, demography, and clinical features of incident cases in 1989. J Neurol, Neurosurg Psychiatry, 1992;55:536-541.

27. Tysnes OB, Vollset SE, Aarli JA. Epidemiology of amyotrophic lateral sclerosis in Hordaland county, western Norway. Acta Neurol Scand, 1991;83:280-285.

28. Veiga-Cabo J, Almazán-Isla J, Sendra-Gutiérrez JM, Pedro-Cuesta J. de. Differential features of motor neuron disease mortality in Spain. Int J Epidemiol, 1997;26:1024-1032.

29. Gordis L. Epidemiology. Philadelphia : W.B. Saunders, 1996, pag. 30-57.

30. US Census Bureau. Summary of the Annual data on demographic, social and economic characteristics: 1985-1994 http:// www.census.gov/population/censusdata/

31. Miller RG. ALS standard of care consensus conference. Neurology, 1997;48(Suppl 4):S1.

32. Brooks BR. Diagnostic dilemmas in amyotrophic lateral sclerosis. J Neurol Sci 1999;164(Suppl 1):S1-9.

33. Ludolph A C, Knirsch U. Problems and pitfalls in the diagnosis of ALS. J Neurol Sci 1999;165(Suppl 1):S14-20. 